\title{
Promises from afar: A model of international student psychological contract in business education
}

Please cite this article as:

Sarbari Bordia, Prashant Bordia \& Simon Lloyd D. Restubog (2015). Promises from afar: a model of international student psychological contract in business education, Studies in Higher Education, 40:2, 212-232.

\begin{abstract}
Despite their significant presence in western business schools, the needs and experiences of international students have not been adequately reflected in the business education literature. We draw upon psychological contract theory - used to understand employer-employee relationships - to develop a novel theoretical model on the international student-business school relationship. Based on the review of psychological contract and international education literatures, we propose that students perceive a variety of institutional obligations arising from explicit and implicit promises made by business schools. Fulfilment or breach of these obligations will impact upon students' educational performance and satisfaction. We also examine ways in which students' cultural orientation might moderate the psychological contract process.
\end{abstract}




\section{Promises from afar: A model of international student psychological contract in business education}

Educating international students is a common activity for universities in countries with strong higher educational credentials (Bennell and Pearce 2003). Over half a million international students enrolled in US universities in 2006-2007, spending US\$14.5 billion in the US (Marklein 2007). The same year, UK universities enrolled 157,000 international students who spent $£ 8.5$ billion (Morris and Russell 2007). In Australia, education is the third largest export earner (after coal and iron ore) with international students spending AU\$12.6 billion a year (Colebatch 2008). The international student diaspora is expected to reach 7.2 million by 2025 (Marklein 2007). Nearly 25\% of international students enrol in business schools (The Economist 2011). The global demand for western-style business education has led to an increased presence of international students, with citizens of Asian countries such as India, China, South Korea, Taiwan and Japan creating large cohorts of international students in business schools (GMAC 2007; Hou 2012; Oleksiyenko, Cheng and Yip 2012).

A growing body of research sheds light on the international students' experiences (e.g., Deumert et al. 2005; Ramburuth and McCormick 2001). Our review of this literature suggests the need for a theoretically-grounded framework that delineates the psychological underpinnings of international students' interactions with business schools, thereby, shedding light on how and why the experiences of international students lead to positive or negative outcomes. A research model aimed at understanding the international student-business schools relationship will benefit both parties. Business schools invest substantial resources in marketing their programs abroad; including, hiring recruitment agencies, sending representatives to educational fairs, and placing advertisements in newspapers with global reach (Sharma 2010; Mazzarol 1998; Mazzarol and 
Soutar 2002). Yet, we know little about the perceptions that marketing ${ }^{1}$ of educational services might create in the minds of prospective students. International students may develop perceptions of institutional obligations from the recruitment process which will have far reaching effects on the satisfaction and engagement of these students (Mai 2005). Perceived breach of obligations may lead to a cycle of negativity in the international student-business school relationship (Chen, Tsui and Zhong 2007). Moreover, the large numbers of international students engaging in business education have resulted in economic benefits for business schools (Bennell and Pearce 2003); with economic benefits comes the responsibility of providing a satisfying socio-educational experience. By accepting international applicants as students, business schools are implicitly obligated to provide an optimal educational environment in which international students can thrive. Therefore, business schools need to develop a deeper understanding of international students' perceptions of institutional obligations and how culture and context shapes the formation of these perceived obligations before and during enrolment.

In this paper, we consider a range of learning and psycho-social experiences of international students in business education through the lens of the psychological contract theory. Why a psychological contract approach? The psychological contract framework sheds light on the perceptions of mutual obligations in relationships, including the origins of these perceptions, when and how these are fulfilled or breached, and what outcomes result from fulfilment/breach (Rousseau 1995). Psychological contract dynamics have been studied extensively in the organisational context and this research demonstrates that employee perceptions of

\footnotetext{
${ }^{1}$ Our paper is not about educational marketing per se. However, we wish to note that the process of educational marketing has consequences for the development of psychological contracts. International students are likely to seek initial information from agents representing the business school. Students are also likely to make sense of marketing materials such as advertisements and brochures to create perceptions of obligation. These perceived obligations based on marketing-related communication are the building blocks of the psychological contract.
} 
fulfilment/breach of organisational obligations have consequences for a productive and satisfying employee-employer relationship (e.g., Rousseau 1995; Zhao et al. 2007). Although

psychological contract has attracted substantial organizational research, its origins lie in the social exchange theory (Blau, 1964) that can explicate several types of relationships. Other areas of research have looked at psychological contracts of volunteers (Starnes 2007), students (WadeBenzoni, Rousseau and Li, 2006) and customers (Koh, Ang and Straub 2004) with consequences of breach/fulfilment towards the satisfaction and performance of individuals. With these insights, business schools can gain a better understanding of student perceptions of the institutions' obligations. Knowledge of students' perceptions can help business schools initiate explicit exchange of information at early stages of the international student-business school relationship so that both parties are better informed of each others' perceptions of obligation in academic and administrative matters (Arena, Arnaboldi and Azzone 2010; Sander et al. 2000). We review the psychological contract and international education literatures to gain insight into how students form psychological contracts and what happens if the contract is breached. Based on the review of the two areas of research, we develop a model of international student psychological contract. We discuss the consequences of this process for student learning, well-being and satisfaction. Theoretical and practical implications as well as limitations and future directions of the model are presented.

\section{Psychological contract research}

Based on social exchange theory, a psychological contract is a mental construct that takes into account an agreement of give and take between an individual and another party (Blau, 1964; Rousseau 2001). The psychological contract develops from individuals' perception of reciprocity within a given relationship. Unlike a written or legally binding contract, a psychological contract 
can be based on both overtly made promises and implicit ones. A student psychological contract is perceived by the student, is subjective, and consists of learning, career and socio-emotional aspects of the student-institution relationship (Bordia, S. et al. 2010). Students may direct different elements of their psychological contracts towards different institutional representatives such as administrators and lecturers (Koskina 2011).

Psychological contracts are built on information from several sources that act as 'contract-makers' and shape the nature of psychological contracts (Dick 2006; Rousseau 1995). In creating a psychological contract, individuals seek and process information based on their existing schema (De Vos, Buyens and Schalk 2005; Sweller and Sweller 2006). The content of a psychological contract include the specific elements that individuals perceive as the other party's obligation towards them (Rousseau 1995). A variety of elements of psychological contracts have been identified, including pay for performance, hours of work, flexibility, positive relationships with supervisors and coworkers, mentoring and career development in the work context (Herriot, Manning and Kidd 1997; Millward-Purvis and Cropley 2003). These elements have been further grouped into two broad types: transactional (short-term and based on exchange of tangible resources such as pay for performance) and relational (long-term, socio-emotional and involving intangible resources such as mentoring; Rousseau 1995).

Individuals evaluate the performance of the other party in the exchange relationship against their psychological contract after commencement of the relationship (Morrison and Robinson 1997). In the work context, as individuals start working in the organisation, they begin to recognize potential gaps between what they believe the organisation is obligated to provide and what they actually receive from the organisation (Thomas and Anderson 1998; Rousseau 1995). Psychological contract breach occurs when the individual perceives the other party to 
have not fulfilled its obligations (Kickul and Lester 2001; Rousseau 1995). Breach is based on a subjective cognitive perception that the other party has not delivered on the promised obligation (Morrison and Robinson 1997). Psychological contract breach leads to negative affective, attitudinal and behavioural outcomes (Zhao et al. 2007). When faced with breach, individuals are unwilling to keep their side of the reciprocal exchange and may reduce inputs or even withdraw from the relationship (Rousseau 1995). Breach of psychological contract can create negative outcomes such as lower performance and reduced psychological well-being (e.g., Zhao et al. 2007). Zhao et al. (2007) emphasized that psychological contract breach or fulfilment is a significant event that individuals are unlikely to take lightly or forget. The ensuing emotional reaction to the event will propagate attitudinal response in individuals such as lack of trust, diminished performance, lower satisfaction and intention to leave (Dick 2006; Kickul and Lester 2001, Robinson and Rousseau 1994). In terms of behavioural outcomes, breach has negative effects on citizenship behaviour and performance and can lead to intention to leave the organisation (Robinson and Morrison 1995). Unlike outcomes of breach, the consequences of fulfilment of psychological contract have been less researched. However, there is some evidence that fulfilment will lead to positive affective outcomes (Conway and Briner 2005).

In the educational context, after active interaction with the business school, international students will perceive the obligations to be fulfilled or breached. From initial orientation programs through to degree completion, students are likely to evaluate the institution on perceived obligations. Perceived breach or delay in fulfilment of obligations will result in negative affective, attitudinal, and behavioural consequences (Bordia, P. et al. 2010; Guest 2004). We discuss the details of such outcomes later in the paper as part of the theoretical model. 
Individuals' cultural orientation is likely to impact upon outcomes of breach. In particular, the cultural constructs of individualism and collectivism have been found to affect how individuals deal with perceptions of psychological contract breach. Societies fostering individualism emphasize the need for independence and distinctiveness among its members. Therefore, individuals are expected to pursue their personal goals (Hofstede, 1980). On the other hand, collectivist cultures expect their members to prioritise the goals of the group over personal goals (Hofstede, 1980). Individuals are expected to consider group harmony and integrity over personal achievements. Thomas, Au and Ravlin (2003) proposed that when faced with breach, individualists are more likely to voice their discontent and reduce citizenship behaviour. On the other hand, collectivists are likely to continue their loyalty in the hope that perceived injustices will correct themselves over time. Individuals with traditional values (e.g., acceptance of authority and social asymmetry; Schwartz 1992) are likely to continue with commitment and citizenship behaviour than their less traditional counterparts (Chen et al. 2007). However, when the personal consequences of breach exceed the zone of tolerance, and individuals have equivalent job alternatives, collectivists are more likely than individualists to exit the relationship. Much of the research that incorporates cultural orientation and psychological contracts has investigated differential outcomes due to culture. We extend the understanding of cultural orientation in the psychological contract process by exploring the role of cultural differences in the development of psychological contract. We also consider how other cultural constructs (e.g., masculinity/femininity, power distance and uncertainty avoidance) impact the psychological contract process.

Despite the mutuality aspect of the relationship, psychological contracts have been primarily studied from the employees' perspective (Zhao et al. 2007). Shore and Tetrick (1994) 
state that organizations have numerous perspectives and organisational agents (e.g., supervisors, human resource managers, co-workers) that may have varying views on employees' obligation towards the organization thus making it difficult to have an organizational psychological contract that can be unanimously endorsed by all agents. The salience of the employee psychological contract dynamics is reflected in theoretical papers which have primarily taken the employee standpoint (e.g., Morrison and Robinson 1997, Rousseau 2001; Suazo, Martínez and Sandoval 2009). In an educational context, students' perception of the psychological contract is the most proximal determinant of students' outcomes (such as satisfaction, motivational and intention to continue with the institution). This is reflected in the growing body of research on student psychological contracts which takes a student perspective (e.g., Bordia, S. et al. 2010; WadeBenzoni, Rousseau and Li 2006). Keeping to this line of enquiry, this paper explores the institutional obligations as perceived by international students in business education.

While all students may have psychological contracts with educational institutions, this paper focuses on international students because these students are in a more vulnerable situation than their domestic counterparts. International students have to overcome cultural and educational differences and sometimes face financial challenges in the new country (ForbesMewett and Nyland 2008; Ramburuth and Tani 2009). Therefore the adjustment process of international students may be more difficult than that of domestic students. In the next section, we review the cultural and contextual factors that create challenging educational and sociocultural experiences for international students.

\section{The context of international students}

We define international students as individuals that are on student visas in foreign countries to undertake higher education. International education has a long history. The first 
record of an international student in Oxford is that of Emo of Friesland in 1190. Oxford still attracts $25 \%$ of its students from overseas (The Economist 2010b). The Economist noted that “foreign students make up 34\% of students in America's elite [business] schools and 85\% in European [business] schools." (2010a, p. 65). For example, nearly $30 \%$ of full-time students enrolled at Harvard Business School in 2007 were international students (Harvard Business School MBA Admission and Information 2010).

International students embody a variety of cultural orientations such as high on collectivism (e.g., Vietnam) or individualism (e.g., Germany). These cultural differences can manifest themselves as different preferences for teaching and learning styles. Cultures high on individualism encourage people to be responsible for their own goal achievements (Hofstede 1986). Thus, individualist societies encourage exploratory and self-directed learning styles. In contrast, cultures high on collectivism expect people to consider the impact of their behaviour on their social group. Members are encouraged to prioritize the groups' goals before their own (Triandis 1995). Hence, collectivist societies emphasize structured and teacher-directed learning styles (Kelly 2009; Ladd and Ruby 1999; Rodrigues 2005). Students from collectivist cultures (e.g., Asian \& Mexican) feel more comfortable in collaborative and co-operative learning contexts, while their counterparts from individualist cultures (e.g., Americans \& Australians) prefer peer-competition (Dunn, Grigs and Price 1993; Gatfield and Gatfield 1994; Kember 2000; Niles 1995; Ramburuth and McCormick 2001; Swisher and Deyhle 1987).

Uncertainty avoidance, power distance, and masculinity/femininity also play a role in students' pedagogic preferences. Uncertainty avoidance relates to the extent to which individuals in a culture are encouraged to deal with situations that are unstructured and unpredictable (Hofstede 1980). In high uncertainty avoidance cultures (e.g., Columbia), structured learning 
activities are preferred, while in low uncertainty avoidance cultures (e.g., USA), exploratory learning is preferred (Rodrigues 2005). Power distance is the presence and acceptance of unequal status in a society (Hofstede 1980). The higher the power distance (e.g., China), the more acceptable it is to have a highly hierarchical teacher-student relationship. Masculine cultures (e.g., Austria) emphasize achievement and competition, while feminine cultures (e.g., Finland) have a social focus including cooperation and harmonious relationships (Hofstede 1980). In terms of learning, students from masculine cultures are more comfortable with abstract notions and theoretical material (e.g., lectures \& text books) than students from feminine cultures (Rodrigues 2005). Learners from masculine, high power distance and uncertainty avoidance cultures prefer passive, well-structured, and teacher-dominated learning styles such as lectures, textbooks and computerized learning. In contrast, learners from feminine, low power distance, and uncertainty avoidance cultures prefer active, self-directed and student-centred learning styles such as case studies, research projects and class discussions (Auyeng and Sands 1996; Rodrigues 2005; Rodrigues, $\mathrm{Bu}$ and Min 2000).

The new and unfamiliar educational style in the host business school makes adaptation a challenge for international students. International students, unsure of the new academic processes, feel less ready to commence education than domestic students (Ramburuth and Tani 2009). In class, the lecturers' accent, rate of speech, and other linguistic aspects are difficult to comprehend for international students (Ramsay, Barker and Jones 1999). New assessment styles often lead to lower educational performance (Burnapp 2006; Lebcir, Wells and Bond 2008). Cumulatively, such academic challenges leave international students less time for relaxation, socializing, or extra-curricular activities (Zhao, Kuh and Carini 2005). The added pressure of performing well in order to justify the expenses involving a foreign education is also a source of 
stress for international students (Ramburuth and Tani 2009). The greater the cultural distance between home and host educational contexts, the greater the challenge for international students (Harvey and Moeller 2009). Middle Eastern and Asian students reported feeling more stressed than European and South American students in an American university (Redmond and Bunyi 1993).

International students encounter economic and socio-emotional challenges as well. International students make commitments by moving countries, living away from friends and family, adjusting to a new culture and managing a budget based on a foreign currency. Students may have given up full-time employment to study internationally and their visas may allow them limited hours of employment. International students may not get work in the areas of their expertise and have to engage in lower paid jobs (e.g., retail). This can lead to economic challenges and lower students' work/life satisfaction (Forbes-Mewett and Nyland 2008). International travel to home country between semesters is expensive for international students, leaving them with limited interaction with friends and family back home thus creating emotional vulnerability (Rajapaksa and Dundes 2002).

Social adjustment in the host country is challenging for international students. Forging meaningful friendships with students of the host country is difficult, leaving students isolated and lonely (Hechanova-Alampay, et al. 2002; Volet and Ang 1998). International students have the added pressure of serving ambassadorial roles for their home cultures (Bartram 2007; Bochner, McLeod and Lin 1977; Sam 2001). They also feel stressed about medical, transportation and accommodation arrangements (Bradley 2000; Burns 1991; Deumert et al. 2005; Forbes-Mewett and Nyland 2008). 
In sum, international students encounter substantial challenges when studying abroad. Business schools play an important role by providing support that helps these students deal with the challenges outlined above. The psychological contract framework draws attention to institutional obligations in the international student-business school relationship. In the next section, we introduce the theoretical model of international student psychological contract in business education.

\section{Theoretical model}

The model of international students' psychological contracts in business education (Figure 1) developed in this paper incorporates the following elements of psychological contract: formation of psychological contracts, the content of psychological contracts, fulfilment or breach, and the resulting outcomes in terms of students' affective state and learning behaviour. We present these elements in three phases. Phase 1 presents the process of formation of psychological contract and the content of psychological contracts. We propose that international students gather and prioritize information about the business school during the pre-enrolment and recruitment phases which influence the content of their psychological contracts (Rousseau 2001). Phase 2 presents international students' evaluation of institutional performance and resultant fulfilment or breach of psychological contracts. As students engage with the business school and experience the educational process, they may perceive their psychological contracts to be either fulfilled or breached (Morrison and Robinson 1997). Phase 3 deals with outcomes of breach/fulfilment. We propose that perceived fulfilment/breach of institutional obligations impacts students' affective outcomes which in turn affect students' attitudinal and behavioural outcomes (Zhao et al. 2007). Fulfilment will create positive affective outcomes and lead to positive attitudes towards the educational experience, business school and culture as well as 
positive behavioural outcomes such as increased participation in class, positive word-of-mouth recommendations to prospective students, and potential decisions to re-enrol in higher order educational programs. In contrast, breach will create negative affective outcomes and lead to negative attitudinal outcomes towards the learning experience, institution and culture as well as negative behavioural outcomes such as absenteeism from class, negative recommendation to prospective students and dropping-out before degree completion. Students' cultural background will again play a role in outcomes of breach. Cultural background will influence how much a student endures unfulfilled institutional obligations as well as how much the student reacts to breach.

[Insert Figure 1 about here]

In the following sections, we discuss each phase of the model. We utilize theoretical insights from the psychological contract literature and apply these to the international student context in business education. We develop general and culturally-contingent propositions detailing each path of the model.

\section{Phase 1: Formation and content of psychological contract}

The formative phase of a psychological contract is important as the foundations of the core perceived obligations from the other party are laid at this stage. International students will gather information from various sources, including the educational institution and their social network in the pre-enrolment stage to create a preliminary psychological contract. The preliminary psychological contract will be revised based on further information gathered from recruitment sources. Information will be gathered and prioritized in accordance with students' cultural orientations. The content of the psychological contract will broadly include educational, 
social and cultural elements. Once again, students' cultural background will play a role in creating specific elements of psychological contracts.

\section{Formation of psychological contracts}

In the following subsection, we discuss the sources that will specifically contribute towards psychological contract formation in the pre-enrolment and recruitment phases.

Sources in the pre-recruitment process. International students start gathering information even before they have made a final decision to study abroad. In fact, the decision to go to a foreign country to gain education often comes after some amount of information seeking that can justify the move and monetary commitment (Andrade 2006; Deumert et al. 2005). The decision making process is challenging for international students due to geographic and cultural distance. Geographic distance makes visiting a business school prior to enrolment expensive or impossible for most international students. Cultural distance makes international students less knowledgeable about the educational and social contexts in which they will have to learn and live in (Andrade 2006). Unlike domestic students, who are familiar with the general structure of educational providers in their country, international students have to understand the structures of business schools and academic programs and often compare them with those of their home country or other international destinations they may be considering. Once the decision has been reached, students actively, and more rapidly, seek further information about the country, business schools and program of their choice. Just as job applicants create assumptions about the organisation from personal and organisational sources (Breaugh 1992), so do international students. Some of these sources may be solicited from the educational provider such as brochures and application packages that business schools send on request from prospective students (Mazzarol 1998). Other information may be gathered from institutional websites and 
advertisements. Further information could be gathered from communication with agents or marketing representatives of the institution. The increase in demand for international education by individuals from several countries (e.g., China, India and Vietnam), has created a niche for agencies that assist prospective students with information about universities and the application process (Mazzarol 1998). Some of these agencies also organize educational fairs which are attended by institutional representatives to provide first hand information about the educational provider. These events are a source of formal as well as informal information-seeking for prospective students.

International students rely on acquaintances, friends and family to gather information about educational providers (Ramsay, Barker and Jones 1999). Students then make sense of the gathered information based on their existing schema regarding educational and cultural issues in the home country and abroad (Paas, Renkl and Sweller, 2003). Students may cross-check information from different formal sources (e.g., business schools, their representatives, agents) with social sources such as friends and family, to establish if the business school or the specific program is worth enrolling in. As schematic knowledge differs from culture to culture, the cultural make up of international students will play an important part in the evaluation process of information from various sources (Sweller and Sweller 2006). Individualist versus collectivist values will play an important role in deciding the reliability of sources in the recruitment phase. People socialized in individualist cultures operate in an autonomous fashion while those socialized in collectivist cultures are embedded in the social context (Schalk and Soeters 2008). Therefore, international students from individualistic cultures are more likely to first gather information from institutional sources before considering social sources. On the other hand, with the cultural orientation of considering the social group's opinion, students from collectivist 
cultures are more likely to gather information from social sources before considering institutional sources. Therefore, we propose that:

Proposition 1 (P1): International students will seek information from educational institutions and social sources to create a preliminary psychological contract. Students from individualist cultures will seek information from educational institutions before considering social sources while those from collectivist cultures will seek information from social sources before considering educational institutions.

Sources in the recruitment process. Based on the information gathered in the prerecruitment phase individuals decide on a specific country, business school and program of study. Individuals then apply for enrolment in the institution of their choice. Individuals now require more specialized information about the country and business school. This process sometimes involves face-to-face or technology-driven interviews, scanning of school websites, online communication with faculty and administrative members of the institution and communication with governmental representatives of the country for visa requirements (Mazzarol 1998). Communication during this stage is often an exchange of information where educational providers require prospective students to share their personal and professional information to judge the capabilities of the student. Like job seekers, this is the time where students actively seek verbal and written promises regarding availability of resources and services that they perceive to be essential for the achievement of their educational, professional and personal goals (Arthur 2001; Suazo, Martínez and Sandoval 2009).

Prospective students may contact other international students studying in the business schools of their choice to establish contact and validate information (Andrade 2006). Based on 
their general assumptions about the institution, students will now seek specific information from other international students in the business school. International students will seek specialized information about life in the host country and city from alumni, current students, and any social contacts they have in the geographic area (Sam 2001). Students will evaluate messages received from sources based on their existing schema to perceive institutional obligations towards them (Sweller and Sweller 2006). These perceptions will lead to a more focused set of institutional obligations which the students will want the business school to fulfil.

International students from individualistic cultures are likely to place greater value on information originating from institutional sources such as brochures, websites and correspondence with representatives of the business school (Hofstede 1986; Ramburuth and McCormick 2001). In case of a discord between information gathered from institutional and social sources, these students are more likely to believe the information from the institutional source. International students from collectivist cultures are more likely to value information originating from social contacts such as family, friends and past/present international students from the same culture (Hofstede 1986; Ramburuth and McCormick 2001). In case of an incongruence between information gathered from institutional and social sources, these students are more likely to believe the information from the social source. Therefore, we propose:

Proposition 2 (P2): International students will actively seek promises from sources in the business school, social sources, as well as interpret written sources to strengthen, modify or add new elements to their preliminary psychological contract. Students from individualistic cultures will place greater value on information gathered from institutional sources while those from collectivist cultures will place greater value on information gathered from social sources. 


\section{Content of psychological contracts}

Among research on student psychological contract (Bordia and Bordia, 2008; Bordia, S. et al. 2010; Koskina 2011; Wade-Benzoni, Rousseau and Li 2006), Wade-Benzoni, Rousseau and Li (2006) investigated psychological contracts in a research educational setting. They found that clarity in students' expectations from supervisors, focused and well-structured task collaboration between advisors and students, clear goals and timely feedback create an effective and attainable psychological contract. Students have implicit and explicit elements to their psychological contracts with business schools (Koskina 2011). A realistic psychological contract between international students and the business school may contain clear understanding of the role of the instructor, well-organized curriculum, social and career support. Based on the information international students gather, they will create a psychological contract that will contain perceived institutional obligations in relation to various aspects of the educational experience such as the quality of teaching; learning resources; assessment formats in the courses; additional support for learning via tutoring and language learning schemes; access to computers, the internet and technical support (Burnapp 2006; Koskina 2011; Treloar et al. 2000; Rai 2002; Spencer 2003). International students will expect the business school to provide them with a comprehensive orientation program when they first arrive to familiarize them with the academic requirements and support available for them (Ramsay, Barker, and Jones 1999). International students, used to different academic environments in home countries, will expect the business school to clearly state what support services are available for them and how they may be used in order to fulfil course and degree requirements (Lebcir, Wells and Bond2008). For example, university libraries can organize workshops that provide hands on information on using online research databases for students (Ishimura, Howard and Moukdad 2007). Similarly, international 
students may want lifestyle-related details to help them adjust into a new socio-cultural environment (Zhao, Kuh and Carini 2005). Information on resources available for mental and physical health issues and insurance schemes will be important for international students who are not used to the healthcare system in the host country (Bradley 2000; Hyun et al. 2007; Russell, Thomson and Rosenthal 2008).

Acculturating into a new socio-educational context is often difficult for international students (Zhang and Dixon 2003). Therefore, students may expect that the members of the business school will understand facets of other religious and cultural backgrounds and will help students understand the host country's cultural norms (Forbes-Mewett and Nyland 2008; Olivas and Li 2006; Poyrazli and Grahame 2007); similar perceptions have been found among multicultural employees' psychological contracts (Williams and Bauer 1994; Zhao and Chen 2008). A safe and energetic campus life may be another perception of institutional obligation (ForbesMewett and Nyland 2008). Given the professional nature of the educational programs in most business schools, mentoring and career support may be an important long-term obligation (Dedrick and Watson 2002). This is similar to perceived obligations regarding training, development, and mentorship in employee psychological contracts (Millward-Purvis and Cropley 2003). Unlike domestic students, international students with limited professional and industry networks in the host country may expect the business school to organize career placement and professional certification for them (Ng 2006; Shen and Herr 2004).

Uncertainty avoidance and masculinity/ femininity will impact upon the elements of psychological contracts. Individuals from strong uncertainty avoidance cultures feel the need to clarify tasks and goals ideally before they start the task. Therefore, international students from strong uncertainty avoidance cultures will create specific and highly defined elements of 
psychological contracts (Hofstede 1986; Ramburuth and Tani 2009). For example, at the time of enrolment, they may be eager to know the assessment format of each course (exams, essays, or group projects, etc.). In contrast, individuals from weak uncertainty avoidance cultures are more relaxed about undertaking tasks that require them to assess specific goals and behavioural patterns as they move forward with the task (Hofstede 1980). International students from weak uncertainty avoidance cultures will create generalized elements of psychological contracts because they are willing to explore the best way of concluding the task as they work on the task. For example, such students may want to know if industry-based guest lecturers are ever invited to classes. Similarly, students from masculine cultures, given their emphasis on achievement and competition, will create specific elements of psychological contract (e.g., assessment format, specific assistance with academic writing, etc.) that they feel will enhance their performance. In contrast, students from feminine cultures will create generalized elements of psychological contract (e.g., stimulating and cooperative learning environment) that may be modified in collaboration with their peers' and lecturers' ideas. Therefore we propose:

Proposition 3 (P3): The content of international students' psychological contract will include academic, cultural, socio-emotional, and career-related elements. The degree of specificity of these elements will be highest for students from masculine and stronger uncertainty avoidance cultures and lowest for students from feminine and weaker uncertainty avoidance cultures. Students from masculine and low uncertainty avoidance cultures as well as feminine and high uncertainty avoidance cultures will have intermediary levels of specificity.

\section{Phase 2: Evaluation and state of psychological contract}


In phase 2, we discuss international students' evaluation of their psychological contracts based on their interaction with the business school. We propose that the performance of the business school will determine perceptions of fulfilment or breach of psychological contracts. Students will also gather information from contacts in other business schools. Such information will assist them in ascertaining whether their psychological contracts have been fulfilled or breached by the business school they are enrolled in.

Evaluation of psychological contract

International students will also compare the current institution with other educational providers in evaluating services available from the business school after enrolment. After commencing studies in a particular business school, international students may engage in social comparison with similar educational institutions (Ramburuth and Tani 2009). Students may be in contact with other international students who have chosen alternate institutions and may provide information about each others' school. Therefore, perceptions of breach may be due to comparison with services provided in other institutions. We expect students from collectivist cultures to engage in more social comparison and information seeking compared to students from individualist cultures (White and Lehman 2005). Collectivists, having more interdependent self, tend to pay greater attention to others in everyday judgments and decision making compared to individualists, who have a more independent self (Markus and Kitayama 1991). Therefore, we propose:

Proposition 4 (P4): Upon commencement of studies, international students will evaluate their psychological contract by considering the performance of the business school and compare it to other business school. Students from collectivist 
cultures are likely to engage in greater social comparison than students from individualist cultures.

Perceptions of fulfilment or breach

International students will evaluate the status of the perceived institutional obligations based on active engagement with the business school after commencement of studies and after comparison with other educational providers (Niles 1955; Sam 2001). This evaluation will lead to perceptions of breach or fulfilment of elements of the psychological contract (Morrison and Robinson 1997). Students may perceive fulfilment of some and breach of other elements of psychological contracts. For example, students may perceive that the institution has met its obligations regarding the quality of educational programs but some aspects of academic support services (such as availability of assistance with academic English) may not have been delivered as promised by the institution (Ramsay, Barker and Jones 1999). In addition, delay in fulfilment of certain elements of psychological contracts may be perceived as breach. For example, if international students from non-English speaking background expect assistance with writing in academic English before submission of their first assignment and find out that these services are provided remedially to students who have not succeeded on the first assignment; they may consider this delay as breach (Lebcir, Wells, and Bond 2008). We do not discuss culture specifically in the context of breach because all students, regardless of their cultural background, have the potential for experiencing breach; albeit for different elements of the contract. Therefore we propose:

Proposition 5 (P5): International students will evaluate the performance of the business school based on the content of their psychological contracts. Obligations that are 
perceived to be delivered on time will be perceived as fulfilled and obligations that are not perceived to be delivered at all or on time will be perceived as breached.

\section{Phase 3: Outcomes of psychological contract fulfilment or breach}

In phase 3, we discuss affective, attitudinal and behavioural outcomes ensuing from fulfilment or breach of psychological contracts. We propose that positive affective outcomes will lead to positive attitudes towards the institution and host country and positive learning-related behaviours, while, negative affective outcomes will lead to negative attitudes towards the institution and host country and negative learning-related behaviours. We also discuss how culture might influence types of behavioural outcomes.

Affective outcomes of fulfilment or breach

Perceptions of fulfilment of institutional obligations will lead to positive affective outcomes for international students. Students may feel a range of positive emotions when elements of their psychological contracts are met. At the very least, they will feel a sense of relief when they perceive the institutional obligations to have been fulfilled (Andrade 2006; Sam 2001). If institutions provide services that are above and beyond the students' perceptions of obligation, it might lead to more positive emotions such as happiness, delight, and a sense of optimism about their educational and professional future (Rousseau 1995). In contrast, perceptions of breach are likely to lead to negative emotional reactions (Morrison and Robinson 1997). International students may feel a sense of violation when they perceive the business school to have not kept its end of the deal (Zhao, Kuh and Carini 2005). The intensity of the emotional reaction may depend on how let down they feel. At the very least, they will be disappointed and frustrated when they encounter breach. Severe breach may lead to more 
complex negative feelings such as depression, sense of betrayal, or loss of trust in the business school (Rousseau 1995; Redmond and Bunyi 1993).

International students' emotional reactions will depend on a qualitative evaluation of the overall breach/fulfilment of psychological contracts. It is likely that students in business education will prioritize certain items of their psychological contracts (Ramburuth and Tani 2009). For example, students may have placed a higher priority on academic quality than on recreational facilities on campus. In a situation where the institution is perceived to have fulfilled its obligations regarding academic quality but breached its obligations regarding recreational facilities, students may feel substantial positive emotions due to fulfilment of their higher order priority and limited negative emotions regarding the breach of their lower order priority. Alternatively, if the business school is perceived to breach its obligation regarding academic quality but to fulfil its obligation by providing excellent recreational facilities, students may feel a strong sense of violation due to the breach of their higher order priority and experience limited positive emotions due to the fulfilment of their lower order priority (Sam 2001). Therefore, it is likely that the extent of emotional reaction for both fulfilment and breach will depend not just on the specific item of psychological contract in question but on the importance students place on the item.

Culture will play a role in the relative importance international students place on items of their psychological contract. In the work context, US employees have been found to react more negatively to breach of intrinsic elements of their contract (e.g., ability to make decisions and be creative; Kickul, Lester and Belgio 2004) and employees from Hong Kong reacted more negatively to breach of extrinsic elements of their contract (e.g., financial remuneration and promotion; Kickul, Lester and Belgio 2004). The emphasis on extrinsic elements of the contract 
can be explained by the impact of Confucianism on Hong Kong Chinese culture that stresses the need to put the welfare of the family first (hence the need for adequate pay) and relinquish individual needs (e.g., autonomy) in favour of workplace harmony (Kickul, Lester and Belgio 2004). Similarly, international students from Confucian inspired cultures may prioritize academic excellence more than other elements of their psychological contracts because they believe that a high standard of academic training will increase their chances of getting a well paying job which will help them take care of their family. Therefore, we propose:

Proposition 6 (P6): International students will experience positive affective outcomes if their psychological contract is fulfilled and negative affective outcomes if their psychological contract is breached. The intensity of the affective outcome will depend on the personal and cultural priority the student places on the specific element of psychological contract.

\section{Attitudinal and behavioural outcomes of fulfilment or breach}

The experience of breach/fulfilment and its resulting emotional state may lead to attitudinal and behavioural outcomes directed towards the educational institution and may have generalized consequences for attitudes towards the host country and its culture. Stemming from the nature and intensity of the affective outcomes, international students will demonstrate a variety of outcomes (Ramburuth and Tani 2009; Redmond and Bunyi 1993). Fulfilment of perceived obligations may lead to better learning outcomes such as high attendance and participation, higher motivation to learn, high performance, satisfaction and a positive attitude towards the business school, country, and culture, re-enrolment for further education in the current school, and positive word-of-mouth recommendation to prospective students. For 
example, an international student initially enrolled for a course-work masters degree may choose to continue on to do a $\mathrm{PhD}$ if perceptions of institutional obligations have been fulfilled.

In contrast, breach of perceived institutional obligations may lead to dissatisfaction with the educational process, business school or culture. For example, students may feel that the business school does not care about the well-being of international students and engage in stereotyping the country and culture as being inconsiderate towards other cultures (ForbesMewett and Nyland 2008). Breach may also lead to outcomes such as absenteeism, lower motivation to learn, lower performance, decision to leave before degree completion, formal and informal complaints to the business school, negative word-of-mouth recommendation to prospective students and lack of interest in social networking (Zhao et al. 2007). For example, students perceiving the business school to have not met its obligation may be dissatisfied with the educational process. These students may choose to leave the school and enrol in another business school that they feel will provide them with practical experiences in the industry.

Based on cultural orientations, different cohorts of international students may react differently to breach. Cultural values pertaining to collectivism and high power distance suggest individuals will act in favour of group harmony (Hofstede 1986; Schalk and Soeters 2008) and are therefore reluctant to voice discontent in early stage of breach. Hence, students from collectivist cultures may continue their commitment towards the business school and their education until they meet with further breaches (i.e., cross their zone of tolerance) before they consider leaving the institution or engaging in negative word-of-mouth (Ramburuth and Tani 2009). In contrast, cultural values pertaining to individualism and low power distance suggest that people will focus on personal gains (Hofstede 1986; Schalk and Soeters 2008) and are 
therefore likely to voice their discontent immediately after they perceive a breach (Ramburuth and Tani 2009). Therefore, we propose:

Proposition 7(P7): The affective reaction to fulfilment or breach of psychological contracts will influence international students' attitudes and behaviour.

Fulfilment will lead to positive outcomes and breach will lead to negative outcomes. Behavioural outcomes will be culturally-contingent, with international students from individualistic and low power distance cultures voicing their discontent and those from collectivist and high power distance cultures continuing their commitment to the business school but exiting when they cross the zone of tolerance. Students from collectivist and low power distance cultures as well as those from individualist and high power distance cultures will display intermediary levels of voicing of discontent and commitment.

\section{Conclusion}

International students comprise a large segment of business school student population and are critical to the 'business of business schools' (Pfeffer and Fong 2004). We hope the review of psychological contract and international education literatures and the theoretical model presented in this paper will assist in creating a deeper understanding of the educational processes of international students. Next, we present the theoretical contributions, limitations and future research directions as well as practical implications of this line of inquiry.

\section{Theoretical contributions}

This paper contributes to the higher education literature by providing a much needed theoretical basis for the investigation of the needs, perceived obligation and socio-educational outcomes of international students. International students come from diverse cultural and 
educational backgrounds which lead to unique experiences with the business school. Under the umbrella of the psychological contract theory, we cover several phases of this experience ranging from the development of perceptions of obligations, the evaluation of the educational experience and outcomes of fulfilment/breach of perceived obligations. We consider culturally-contingent outcomes in these phases. The paper also contributes towards the employee psychological contract literature. Much of the research in this area has concentrated on breach and its outcomes, while the process of psychological contract formation is under researched (De Vos, Buyens, and Schalk 2005). Indeed, little effort has been devoted to looking at the entire psychological contract process starting from formation to outcomes of breach (Guest 2004). The model presented in this paper encompasses the full 'life-cycle' of the psychological contract dynamics over three phases: formation, evaluation, and outcomes.

\section{Limitations and future research directions}

Our model requires empirical testing. Future research can conduct qualitative or quantitative research that tests the propositions specified in the model. Given the nascent state of research in this area, qualitative research investigating the sources that lead to the formation of psychological contracts and the nature of student psychological contracts will help further development of the theoretical framework. Also, observations of the recruitment process and analysis of formal and informal communication between the business school (including websites and brochures) and prospective students will aid the understanding of psychological contract development. Qualitative research can also lead to the construction of context-specific measures. Such measures will enable larger scale quantitative studies on international students’ psychological contracts in business education. Laboratory experimental studies will assist in the understanding of the signaling effect of advertisements and websites to prospective students. 
Longitudinal research on international student psychological contracts may also shed light on the dynamic nature of contract development. Students may gravitate towards a more realistic and attainable contract after exposure to the educational institution. Another interesting aspect to investigate would be whether, with the experience of living in the host country, international students and domestic students have similar psychological contracts due to cultural convergence. With empirical work the model could be expanded to include different sub-types of contract (much like transactional and relational forms of psychological contracts in the workplace context; Rousseau, 1995).

A limitation of the model is that it takes into account only the international students' perspective. Business schools and their representatives may also have psychological contracts with these students. Future research should consider the role of the various stakeholders in creating psychological contracts for international students. Therefore, data should be gathered from recruiters, agents, prospective and current students, alumni, academics, administrators and support staff members.

Our evaluation of the cultural contexts of international students is driven by a widely used model of culture (i.e., Hofstede 1980) in several fields of the social sciences including international education, business education, international business and organizational behaviour. However, one caveat of this model is its reliance on comparison between cultures (Morris, et al. 1999). It does not take into account unique cultural constructs that may be integral to one culture but not comparable with constructs in other cultures. Future research should consider the impact of unique cultural phenomena on international student psychological contract processes.

While we situate the model of international student psychological contract in the business education context, the model can be adjusted to help understand international student 
psychological contracts in most other higher educational disciplines. We present the case of business education given the fact that a large percentage of international students studying in countries such as Australia, Canada, the United Kingdom and the United States of America enrol in business schools (The Economist 2011). The content and priority of elements of international students' psychological contracts may vary between disciplines in higher education. For example, international students enrolling in fields of higher education that are more applied in nature (e.g., business; engineering) may give higher priority to career-related elements in their psychological contracts than students enrolled in other disciplines such as degrees in humanities or sciences. Future research can modify the current model to fit the context of other academic disciplines such as education, engineering or medicine.

\section{Practical implications for business schools}

Apart from much needed theory building on international student psychological contracts in business education, the examination of student psychological contract can help business schools gain information regarding the socio-educational experiences of international students. Knowledge of the development of psychological contracts can help business schools create recruitment and advertisement material that help create realistic perceptions of obligations, the fulfilment of which will lead to a positive educational experience for students and be a source of reputational gain for the institution. Knowledge of the role culture plays in the psychological contract process will assist business schools in creating culturally-specific marketing strategies. Periodic evaluation of international students' psychological contracts will help modify any unrealistic psychological contracts, and aid in building a supportive environment where international students will academically, socially and emotionally thrive in the business school, thus in turn enhancing the reputation of the school. 


\section{References}

Andrade, M.S. 2006. International students in English-speaking universities: Adjustment factors. Journal of Research in International Education 5, no. 2: 131-154.

Arena, M., M. Arnaboldi, and G. Azzone. 2010. Student perceptions and central administrative services. Studies in Higher Education 35, no. 8: 941-59.

Arthur, D. 2001. The Employee Recruitment and Retention Handbook. New York: Amacom.

Auyeung, P., and J. Sands. 1996. A cross cultural study of the learning style of accounting students. Accounting and Finance 36, no. 2: 261-274.

Bartram, B. 2007. The sociocultural needs of international students in higher education: A comparison of staff and student views. Journal of Studies in International Education 11, no. 2: $205-214$.

Bennell, P., and T. Pearce. 2003. The internationalisation of higher education: Exporting education to developing and transitional economies. International Journal of Educational Development 23, no. 2: 215-232.

Blau, P. 1964. Exchange and power in social life. New York: Wiley.

Bochner, S., B.M. McLeod, and A. Lin. 1977. Friendship patterns of overseas students. Journal of Social Psychology 110, no. 4: 265-272.

Bordia, P., S.L.D. Restubog, S. Bordia, and R.L. Tang. 2010. Breach begets breach: Trickledown effects of psychological contract breach on customer service. Journal of Management 36, no. 6: $1578-1607$.

Bordia, S., and P. Bordia. 2008. Promises from afar: The nature of international students psychological contracts in management education. In G.T. Solomon (Ed.), 2008 Annual 
Meeting Proceedings (CD) for US Academy of Management Annual Meeting. Anaheim, USA. ISSN: 1543-8643: 1-6.

Bordia, S., E. Hobman, S.L.D. Restubog, and P. Bordia. 2010. Advisor-student relationship in business education project collaboration: A psychological contract perspective. Journal of Applied Social Psychology 40, no. 9: 2360-2386.

Bradley, G. 2000. Responding effectively to the mental health needs of international students. Higher Education 39, no. 4: 417-433.

Breaugh, J. 1992. Recruitment: Science and Practice. Boston: PWS-Kent.

Burnapp, D. 2006. Trajectories of adjustment of international students: U-curve, learning curve, or third space. Intercultural Education 17, no. 1: 81-93.

Burns, R.B. 1991. Study and stress among first year overseas students in an Australian university. Higher education Research and Development 10, no. 1: 61-77.

Chen, Z.X., A.S. Tsui, and L.F. Zhong. 2007. Reactions to psychological contract breach: a dual perspective. Journal of Organizational Behavior 29, no. 5: 527-548.

Colebatch, T. 2008. Education exports score top marks. The Age, June 20.

Conway, N., and R. Briner 2005. Understanding psychological contracts at work: A critical evaluation of theory and research. New York: Oxford University Press.

Dedrick, R.F., and F. Watson, 2002. Mentoring needs of female, minority, and international graduate students: A content analysis of academic research guides and related print material. Mentoring and Tutoring 10, no. 3: 275-289.

Deumert, A., S. Marginson, C. Nyland, G. Raima, and E. Sawir. 2005. Global migration and social protection rights. Global Social Policy 5, no. 3: 329-352. 
De Vos, A., D. Buyens, and R. Schalk. 2005. Making sense of a new employment relationship: Psychological contract-related information seeking and the role of work values in locus of control. International Journal of Selection and Assessment 13, no. 1: 41-52.

Dick, P. 2006. The psychological contract and the transition from full to part-time police work. Journal of Organizational Behavior 27, no. 1: 37-58.

Dunn, R., S.A. Griggs, and G.E. Price. 1993. Learning styles of Mexican American and AngloAmerican elementary school students. Journal of Multicultural Counseling and Development 21, no. 4: 237-247.

Forbes-Mewett, H., and C. Nyland. 2008. Cultural diversity, relocation, and the security of international students at an internationalised university. Journal of Studies in International Education 12 no. 2: 181-203.

Gatfield, T., and R. Gatfield. 1994. The Asian and the Australian student higher education learning process: Is there a need to modify the Australian teaching methodologies to draw on Asian learning processes? An exploratory investigation. Paper presented at the HERDSA Annual Conference July 2-5, in Canberra, Australia.

GMAC. 2007. Asian Geographic Trend Report for Examinees Taking the Graduate Management Admissions Test 2002-2006. McLean, VA: Author.

Guest, D. 2004. Flexible employment contracts, the psychological contract and employee outcomes: an analysis and review of the evidence. International Journal of Management Reviews 5/6, no. 4: 1-19.

Harvard University. 2010. Harvard Business School MBA Admission and Information. http://www.businessschooladmission.com/harvard-business-school/ Accessed on June 12, 2011. 
Harvey, M. and M. Moeller. 2009. Expatriate mangers: A historical review. International Journal of Management Reviews 11, no. 3: 275-296.

Hechanova-Alampay, R., T.A. Beerh, , N.D. Christiansen. and Van Horn, R. K., 2002. Adjustment and strain among domestic and international student sojourners: A longitudinal study. School Psychology International 23, no. 4: 458-474.

Herriot, P., W.E.G. Mannings, and J.M. Kidd. 1997. The content of psychological contract. British Journal of Management 8, no. 2: 151-162.

Hofstede, G. 1980. Culture's Consequences: International Differences in Work-related Values. Beverly Hills, CA: Sage.

Hofstede, G. 1986. Cultural differences in teaching and learning. International Journal of Intercultural Relations 10, no. 3: 301-320.

Hou, A.Y. 2012. Quality in cross-border higher education and challenges for the internationalization of national quality assurance agencies in the Asia-Pacific region: The Taiwanese experience, Studies in Higher Education DOI:10.1080/03075079.2011.646258.

Hyun, J., B. Quinn, T. Madon, and S. Lustig. 2007. Mental health need, awareness, and use of counseling services among international graduate students. Journal of American College Health 56, no. 2: 109-118.

Ishimura, Y., V. Howard, and H. Moukdad. 2007. Information literacy in academic libraries: Assessment of Japanese students' needs for successful assignment completion in two Halifax universities. The Canadian Journal of Information and Library Science 31, no. 1: 1-26.

Kelly, P. 2009. Group work and multicultural management education. Journal of Teaching in International Business 20, no. 1: 80-102. 
Kember, D. 2000. Misconceptions about the learning approaches, motivation and study practices of Asian students. Higher Education 40, no. 1: 99-121.

Kickul, J., S.W. Lester, and E. Belgio. 2004. Attitudinal and behavioral outcomes of psychological contract breach: A cross cultural comparison of the United States and Hong Kong Chinese. International Journal of Cross Cultural Management 4, no. 2: 229-252.

Kickul, J. and S.W. Lester. 2001. Broken promises: Equity sensitivity as a moderator between psychological contract breach and employee attitudes and behavior. Journal of Business and Psychology 16, no. 2: 191-217.

Koh, C., S. Ang, and D.W. Straub. 2004. IT Outsourcing Success: A Psychological Contract Perspective. Information Systems Research 15 no. 4: 356-373.

Koskina, A. 2011. What does the student psychological contract mean? Evidence from a UK business school, Studies in Higher Education DOI:10.1080/03075079.2011.618945.

Ladd, P.D., and R. Ruby. 1999. Learning style and adjustment issues of international students. Journal of Education in Business 74, no. 6: 363-367.

Lebcir, R. M., H. Wells, and A. Bond. 2008. Factors affecting academic performance of international students in project management courses: A case study from a British post 92 university. International Journal of Project Management 26, no. 3: 268-274.

Mai, L.W. 2005. A comparative study between UK and US: The student satisfaction in higher education and its influential factors. Journal of Marketing Management 21, no. 7-8: 859878.

Marklein, M.B. 2007. USA sees first increase in foreign students since 9/11. USA Today, December 11. 
Markus, H.R. and S. Kitayama. 1991. Culture and the self: Implications for cognition, emotion, and motivation. Psychological Review 98, no. 2: 224-253.

Mazzarol, T. 1998. Critical success factors for international education marketing. International Journal of Educational Management 12, no. 4: 163-175.

Mazzarol, T., and G.N. Soutar. 2002. "Push-pull” factor influencing international student destination choice. International Journal of Educational Management 16, no. 2: 82-90.

Millward-Purvis, L.J., and M. Cropley. 2003. Psychological contracting: Processes of contract formation during interviews between nannies and their 'employers'. Journal of Occupational and Organizational Psychology 76, no. 2: 213-241.

Morris, N., and B. Russell. 2007. Overseas students boost UK economy by £8bn a year. The Independent, November 16.

Morris, M.W., K. Leung, D. Ames, and B. Lickel. 1999. Views from inside and outside: Integrating Emic and Etic Insights about Culture and Justice Judgment. The Academy of Management Review 24, no. 4: 781-796.

Morrison, E.W., and S.L. Robinson. 1997. When employees feel betrayed: A model of how psychological contract violation develops. Academy of Management Review 22, no. 3: 226256.

Ng, K.M. 2006. International students in CACREP-Accredited counselling programs. Journal of Professional Counseling: Practice, Theory, and Research 34, no. 1:20-32.

Niles, S. 1995. Cultural differences in learning motivation and learning strategies: A comparison of overseas and Australian students at an Australian university. International Journal of Intercultural Relations 19, no. 3: 369-385. 
Oleksiyenko, A., K.M. Cheng, and H.K. Yip. 2012. International student mobility in Hong Kong: private good, public good, or trade in services?. Studies in Higher Education DOI:10.1080/03075079.2011.630726.

Olivas, M., and C.S. Li. 2006. Understanding stressors of international students in higher education: What college counsellors and personnel need to know. Journal of Instructional Psychology 33, no. 3:217-222.

Paas, F., A. Renkl, and J. Sweller. 2003. Cognitive load theory and instructional design: recent development. Educational Psychologist 38, no. 1: 1-4.

Pfeffer, J., and C.T. Fong. 2004. The business school 'business': Some lessons from the US experience. Journal of Management Studies 41, no. 8: 1501-1520.

Poyrazli, S., and K.M. Grahame. 2007. Barriers to adjustment: Needs of international students within a semi-urban campus community. Journal of Instructional Psychology 34, no. 1: 2845.

Rai, G.S. 2002. Meeting educational needs of international students: A perspective of US schools. International Social Work 45, no. 1: 21-33.

Rajapaksha, S., and L. Dundes. 2002. It's a long way from home: International student adjustment to living in the United States. College Student Retention 4, no. 1: 15-28.

Ramburuth, P., and J. McCormick. 2001. Learning diversity in higher education: A comparative study of Asian international and Australian students. Higher Education 42, no.3: 333-350.

Ramburuth, P., and M. Tani. 2009. The impact of culture on learning: exploring student perceptions. Multicultural Education and Technology Journal 3, no. 3: 182-195. 
Ramsay, S., M. Barker. and E. Jones. 1999. Academic adjustment and learning processes: A comparison of international and local students in first-year university. Higher Education Research and Development 18, no. 1: 129-144.

Redmond, M.V., and J.M. Bunyi,. 1993. The relationship of intercultural communication competence with stress and the handling of stress as reported by international students. International Journal of Intercultural Relations 17, no. 2: 235-254.

Robinson, S., and E.W. Morrison. 1995. Psychological contracts and OCB: The effect of unfulfilled obligations on civic virtue behavior. Journal of Organizational Behavior 16, no. 3: 289-298.

Robinson, S., and D. Rousseau. 1994. Violating the psychological contract: Not the exception but the norm. Journal of Organizational Behavior 15, no. 3: 245-259.

Rodrigues, C. 2005. Culture as a determinant of importance level business students place on ten teaching/learning techniques: A survey of university students. The Journal of Management Development 24, no. 7: 608-621.

Rodrigues, C., N. Bu, and B. Min. 2000. Learners training approach preference: national culture as a determinant. Cross Cultural Management: An International Journal 7, no. 1: 23-32.

Rousseau, D.M. 1995. Psychological Contracts in Organizations: Understanding Written and Unwritten Agreements. Newbury Park, CA: Sage.

Rousseau, D.M. 2001. Schema, promises and mutuality: The building blocks of the psychological contract. Journal of Occupational and Organizational Psychology 74, no. 4: $511-541$.

Russell, J., G. Thomson, and D. Rosenthal. 2008. International student use of university health and counseling services. Higher Education 56, no. 1: 59-75. 
Sam, D.L. 2001. Satisfaction with life among international students: An exploratory study. Social Indicators Research 53, no. 3: 315-337.

Sander, P., K. Stevenson, M. King, and D. Coates. 2000. University students' expectations of teaching. Studies in Higher Education 25, no. 3: 309-23.

Schalk, R., and J Soeters. 2008. Psychological contracts around the globe: Cultural agreements and disagreements. In P.B. Smith, M.F. Peterson and D.C. Thomas (Eds.), The Handbook of Cross-Cultural Management Research, 117-133. Thousand Oaks, CA: Sage.

Schwartz, S.J. 1992. Universals in the content and structure of values: Theory and empirical tests in 20 countries. In M. Zanna (Ed.), Advances in Experimental Social Psychology, 25, 1-65. New York: Willey.

Sharma, S.S. 2010. Fee-ling the pinch: Falling enrolments force American universities to pay to get students. Businessworld, May 3.

Shen, Y.J., and E.L Herr. 2004. Career placement concerns of international graduate students: A qualitative study. Journal of Career Development 31, no. 3: 15-29.

Shore, L.M., and L.E. Tetrick. 1994. The psychological contract as an explanatory framework in the employment relationship. In C. L. Cooper \& D. M. Rousseau (Eds.) Trends in Organizational Behavior, 1: 91-109. New York: John Wiley \& Sons.

Spencer, A. 2003. Facilitating the academic success of international students. Teaching Theology and Religion 6, no. 3: 164-168.

Starnes, B.J. 2007. An analysis of psychological contracts in volunteerism and the effect of contract breach on volunteer contributions to the organization. The International Journal of Volunteer Administration XXIV, no 3: 31-41. 
Suazo, M., P. Martínez, and R. Sandoval. 2009. Creating psychological and legal contracts through human resource practices: A signaling theory perspective. Human Resource Management Review 19, no. 2: 154-166.

Sweller, J., and S. Sweller. 2006. Natural information processing systems. Evolutionary Psychology 4, no. 2: 434-458.

Swisher, K., and D. Deyhle. 1987. Styles of learning and learning styles: Educational conflicts of American Indian/Alaskan native youth. Journal of Multilingual and Multicultural Development 8, no. 4: 345-360.

The Economist. 2010a. Business education: Case studies. May 8: 67.

The Economist. 2010b. Foreign university students: Will they still come?. August 7: 55-57.

The Economist. 2011. Schumpeter: Tutors to the world. June 11: 74

Thomas, H.D.C., and N. Anderson. 1998. Changes in newcomers' psychological contracts during organizational socialization: A study of recruits entering the British Army. Journal of Organizational Behavior 19, no. S1: 745-767.

Thomas, D.C., K. Au, and E.C. Ravlin. 2003. Cultural variation and the psychological contract. Journal of Organizational Behavior 24, no. 5: 451-471.

Treloar, C., N. McCall, I. Rolfe, S.A. Pearson, G. Garvey, and A. Heathcote. 2000. Factors affecting progress of Australian and international students in a problem-based learning medical course. Medical Education 34, no. 9: 708-715.

Triandis, H. 1995. Individualism-Collectivism: New Directions in Social Psychology. Boulder, CO: Westview Press. 
Volet, S.E., and G. Ang. 1998. Culturally mixed groups on international campuses: An opportunity for inter-cultural learning. Higher Education Research and Development 17, no. 1: $5-23$.

Wade-Benzoni, K.A., D.M. Rousseau, and M. Li. 2006. Managing relationships across generations of academics: Psychological contracts in faculty-doctoral student collaborations. International Journal of Conflict Management 17, no. 1: 4-33.

White, K., and D.R. Lehman. 2005. Culture and social comparison seeking: The role of selfmotives. Personality and Social Psychology Bulletin 31, no. 2: 232-242.

Williams, M.L., and T.N. Bauer. 1994. The effect of a managing diversity policy on organizational attractiveness. Group and Organization Management 19, no. 3: 295-308.

Zhang, N., and D.N. Dixon. 2003. Acculturation and attitudes of Asian international students toward seeking psychological help. Multicultural Counseling and Development 31, no. 3: $205-222$.

Zhao, C.M., G.D. Kuh, and R.M. Carini. 2005. A comparison of international students and American student engagement in effective educational practices. Journal of Higher Education 76, no. 2: 209-231.

Zhao, H., and L. Chen. 2008. Individualism, collectivism, selected personality traits, and psychological contract in employment: A comparative study. Management Research News 31, no. 4: 289-304.

Zhao, H., S.J. Wayne, B.C. Glibkowski, and J. Bravo. 2007. The impact of psychological contract breach on work-related outcomes: A meta-analysis. Personnel Psychology 60, no. 3: $647-680$. 
FIGURE 1: Culturally-contingent model of international students' psychological contract (PC) in business education

Phase 1:

Formation and content of PC

\begin{tabular}{|l|}
\hline \multicolumn{1}{|c|}{ Formation of PC } \\
\hline $\begin{array}{l}\text { Pre-recruitment sources }(P 1) \text { : Information } \\
\text { gathered from social and institutional sources } \\
\text { - Students from collectivist cultures will gather } \\
\text { information from social sources before } \\
\text { approaching institutional sources }\end{array}$ \\
- Students from individualist cultures will gather \\
information from institytional sources before \\
aboroaching social soutces
\end{tabular}

\section{Content of PC $(P 3)$}

Perceptions of institutional obligations will include academic, career-related, socio-emotional and cultural elements

- Students from feminine and low uncertainty avoidance cultures will have generalized content of psychological contract

-Students from masculine and high uncertainty avoidance cultures will have specific content of psychological contract.
Phase 2:

Evaluation and state of PC

Evaluation of PC (P4)

- Students from collectivist cultures will engage more in social comparison than

studgantc fromindividualict

All students have the
potential to experience
breach regardless of
their cultural
orientation

t:

Breach: Negative affect (violation)

- Intensity of affective outgome will depend upon culture-based importanc of the elements breached

Fulfillment: Positive attitude towards host culture and business school, satisfaction, increased motivation, increased class participation, positive word of mouth and decision to re-enroll in further degrees

Breach: Negative attitude towards host culture and business school, dissatisfaction, absenteeism, low motivation, negative word of mouth and exit before degree completion

- Students from individualist and low power distance cultures will voice their discontent early

- Students from collectivist and high power distance cultures will be more tolerant of breach but will exit upon crossing the zone of tolerance 
